\author{
Esthir Lemi \\ Elena Vosnaki
}

\title{
PRAXIS - ODDECH JAKO OZNAKA NASKÓRKOWOŚCI
}

\section{Wprowadzenie}

Niniejszy artykuł koncentruje się na wybranych powierzchniowych aspektach sztuki, które choć powinny być uwzględniane podczas analiz estetycznych współczesnych dzieł sztuki, są często pomijane jako nieadekwatne. Jest to tym bardziej istotne, że przecież sztuka opiera się na zasadzie „najpierw doświadczenie, później wyjaśnienie”. Nawet jeśli uznajemy taniec za sztukę ciężaru i równowagi, musimy pamiętać, że kinestetycznie obejmuje on także wszystkie inne zmysły, szczególnie te „powierzchniowe”: dotyk i powonienie. Innymi słowy - akcentuje to, jak stymulują one pamięć i komunikację. W aforyzmie 256 Nietzsche przywołuje termin opisujący bodziec dotykowy, nazywając go Hautlichkeit (ang. epidermality) - „naskórkowością?. Nietzsche nie był zwolennikiem powierzchowności w życiu, ale jednocześnie posługuje się skórą - skomplikowanym, wrażliwym narządem czucia, który łączy świat wewnętrzny (ciało i jego funkcje) ze światem zewnętrznym - do skonstruowania terminu, który otwiera nowy obszar refleksji dotyczącej społeczeństwa i sztuki (Nietzsche 1882).

Wszyscy ludzie głębocy pokładają szczęśliwość swą $\mathrm{w}$ tem, by być raz podobnymi do ryb latających i igrać na najwyższych szczytach fal; jako najlepsze cenią w rzeczach to, że posiadają one powierzchnię: swą naskórkowość - sit venia verbo (Nietzsche 1882).

Biorąc pod uwagę powyższe, a także niedawno dokonane odkrycie, że człowiek potrafi wyczuć bilion zapachów (Bushdid i in. 2014), artyści zyskują nową paletę, na której mogą dowolnie mieszać różne formy sztuki, na chwilę odstawiając na bok to, co wyłącznie wzrokowe, i przywracając równowagę pomiędzy różnymi zmysłami. Jeśli przyjmiemy, że wierzchołkiem góry lodowej w badaniu „naskórkowości” jest interakcja dotykowa, stanie się jasne, że potrzebujemy poszerzenia wiedzy z zakresu choreografii, by odkryć możliwości, jakie daje komunikacja na tym poziomie. W niniejszym artykule zaprezento- 
wano strategię choreograficzną opartą na naskórkowości, rozumianej tu jako interakcja pomiędzy publicznością a tancerzami poprzez to odkryte na nowo medium zmysłowe.

\section{Zapach potu jako zapach sukcesu}

W dzisiejszym społeczeństwie elementem wyznaczającym równowagę pomiędzy tym, co erotyczne, a tym, co automatyczne [robotic], może być pot. Wobec tego tworzy się bezzapachowe, sztuczne środowiska, w szkołach zaś uczy się, że przymiotnik „bezzapachowy” w zasadzie oznacza „cywilizowany”. Choreografia wydaje się obszarem, w którym zapach mógłby zostać użyty ponownie - np. jako sygnalizacja zmiany nastroju (strach, satysfakcja itd.). Dzięki temu widownia mogłaby lepiej zrozumieć abstrakcyjnie aktualizowane w ruchu sytuacje społeczne, wykorzystując do tego szczególną mowę ciała - zmysł powonienia. Wymagałoby to jednak przywrócenia zapomnianych przez nas kompetencji.

Z jednej strony nieustannie poznajemy nowe, niezwykłe możliwości i funkcje ludzkiego mózgu oraz zmysłów (Lang 2000; Yeshurun, Sobel 2010), z drugiej - istnieją podstawy, by sądzić, że coraz trudniej jest nam odróżnić to, co sztuczne, od tego, co naturalne, a to może w konsekwencji prowadzić do zatracenia człowieczeństwa (Lemi 2016). Naskórkowość, jako perspektywa badawcza w tańcu, może pomóc rozpoznać nowe aspekty ćwiczenia umiejętności rozpoznawania zmian zachodzących w ciele. To z kolei może prowadzić do głębszej komunikacji z nim performerów i uczestników. Byłoby to spójne z coraz częstszym trendem w sztuce do wykorzystywania zależności pomiędzy funkcjonowaniem mózgu a naszym postrzeganiem świata. W Historii brudu Katherine Ashenburg tak podsumowuje swoją narrację poświęconą tej problematyce:

Przyszłość czystości jest zagadką, zależną, jak zawsze, od materialnych zasobów danego społeczeństwa i ewolucji jego mentalności. Nic, na przykład, nie zmieniłoby naszych nawyków kąpielowych szybciej i gruntowniej niż poważny deficyt wody. Jedna rzecz jest pewna. Za sto lat ludzie będą patrzeć z rozbawieniem, jeśli nie zdumieniem, na to, co uchodziło za higieniczną normę na początku XXI wieku (Ashenburg 2009, s. 248).

Sztuka może prowokować delikatniejszy sposób komunikacji pomiędzy artystą a widzem, czy też szerzej - publicznością. Jednocześnie nie istnieje osobne, rozbudowane słownictwo służące do opisania wrażeń zapachowych odczuwanych przez uczestników aktu sztuki. Nie powinno zatem dziwić, że zapachu nie wymienia się wśród bodźców zmysłowych uwzględnianych w procesie świadomej komunikacji artystycznej.

Gruczoły apokrynowe skóry są odpowiedzialne za wytwarzanie przez człowieka „ludzkich” zapachów, sama skóra zaś wyznacza granicę pomiędzy we- 
wnętrznym światem biologii (w którym zasadniczo wszyscy jesteśmy równi) oraz światem zewnętrznym, otoczeniem (któremu podlegamy, tym samym nie mając nad nim kontroli). Dlatego staje się ona środkiem interakcji i interkomunikacji pomiędzy tymi dwiema płaszczyznami egzystencji. Obrazują to badania Ramachandrana (2000), które dowodzą, że często nie potrafimy określić, czy coś nam się podoba, czy nie, ponieważ tak silnie działa na nas siła konwenansu. Dlatego tak wielu ludzi, którzy odwiedzają muzeum, poci się jak mysz na widok obrazu Picassa, nawet jeśli tak naprawdę uważają go za bohomaz. Nasz umysł wyraża aprobatę dla czegoś poprzez uwalnianie potu, podczas gdy cywilizacja nie pochwala lub wręcz wypiera to zjawisko. Ten sam mechanizm działa, gdy mamy ochotę na sen albo gdy decydujemy, że jedno zdjęcie nam się podoba, a inne nie. Umiejętność dobrego odczytywania zmysłów mogłaby skutkować tym, że dokonując wyboru, bralibyśmy pod uwagę nie tylko naszą wolę, ale i potrzeby komunikowane przez ciało.

Edukacja taneczna jest doskonałym sposobem przywrócenia temu wspaniałemu narzędziu poznania siebie i zrozumienia innych należnego miejsca. Najlepiej zrobić to poprzez wykorzystanie naskórkowości jako elementu choreografii, która wymaga interakcji pomiędzy uczestnikami wydarzenia, oraz zastosowanie nowej terminologii do opisania ruchu i działań stymulujących zapach i pot - innej niż metafory odnoszące się do aspektów wizualnych, muzycznych czy poetyckich (np. „ostry”, „żywy”, „przenikliwy”). Uzupełniłoby to nasze ubogie słownictwo określające zapach. W tym celu korzystamy z określeń przynależnych dotykowi, dźwiękowi lub wzrokowi, np. ostry zapach octu winnego czy delikatny i przejrzysty jak promień słońca zapach perfum. Sposobem na połączenie wszystkich zmysłów i ponowne wykorzystanie pełnej ich palety może okazać się archiwum choreografii, która wykorzystuje naskórkowość i podpowiada nowe definicje związanych z nią zjawisk, przywracając ją codziennemu dyskursowi.

\section{Wspomnienie strachu - pot jako znak przełomu}

Ludzki oddech, którego woń stanowi złożoną mieszankę zapachu strawionych i metabolizowanych produktów przemiany materii, oraz pot wydalany przez skórę to komunikaty przekazywane mimo wszystko na poziomie czysto chemicznym, nie zaś intelektualnym. Dlatego zapach może działać w charakterze swego rodzaju dokumentu tożsamości dla superego sztuki. W tańcu wykorzystuje się wysiłek fizyczny - człowiek poci się, wydzielając swoje emocje każdym porem skóry, przekazując strach, niepewność, nieopisaną ulgę lub niewysłowioną radość, ale też tęsknotę i smutek. W procesie kreowania postaci przez performera świetnym pomysłem może być rozpoczęcie od zapachu, a w dalszej kolejności ujawnianie i dopasowywanie innych parametrów. To swoista kontrpropozycja w stosunku do tego, co proponuje się we współczesnym sztucznym, multimedialnym (choć głównie obrazkowym) świecie. 
W tym kontekście czytelne staje się również to, że na scenie, tak jak i w normalnym życiu, nierozpoznawalność zapachu powinna oznaczać niebezpieczeństwo: brak zdolności rozróżnienia między tym, co naturalne, a tym, co sztuczne. Sytuacja, w której to, co sztuczne staje się miarą tego, co naturalne, oddala nas od pierwotnego zastosowania zmysłu powonienia. Za przykład może tu posłużyć ściśle powiązany z węchem zmysł smaku. Dla wielu dzieci smak jogurtu truskawkowego spreparowanego w laboratorium wydaje się bardziej naturalny niż smak prawdziwych truskawek. Nasz naturalny zapach stanowi mieszankę zapachów różnych wydzielin naszego ciała. Zamiast tego czujemy zapachy sztucznie mu nadawane (mydła, dezodorantu, produktów do pielęgnacji włosów, płynu do zmiękczania tkanin, perfum, maści leczniczych, leków). Jak zatem widać, umyka nam to, co pierwotnie ludzkie. Gdyby robot mógł mieć swój zapach, sprawilibyśmy, że pachniałby jak człowiek - tak jak robi się to w przypadku sztucznego nadawania smaku jogurtom. Możemy więc nazwać ten proces dehumanizacją człowieka, coraz bardziej przypominającego robota. Poprzez choreografię możemy jednak pójść w przeciwnym kierunku, rozpoczynając narrację z poziomu naskórkowości i odzyskując ją dla sztuki.

Elena Vosnaki sugeruje użycie terminu Umberto Eco „intertekstualność” jako łącznika pomiędzy „książkami mówiącymi o innych książkach” a rizomatycznymi skojarzeniami, które wywołuje zapach:

Pod żadnym więc względem nie zajmujemy się tu odtwórczymi i prozaicznymi projektami zapachowymi, które poruszają się po wydeptanych ścieżkach, mając na względzie tylko to, by towar był chodliwy. Skupiamy się na projektach świadomie nawiązujących do dzieł sztuki, które jak dusza skryta pod płaszczem skóry, uwalniają się z ciała, łącząc się ze sobą w zgodnym tańcu (Vosnaki 2015, tłum. własne).

Wykorzystując wspomnianą wcześniej „bezzapachową” estetykę, można zarazem wrócić do norm dawno wypracowanych przez wiedzę dyskursywną. Nawet Freud uważał węch za zmysł podstawowy. Za sprawą chodzenia w pozycji pionowej człowiek wyzbył się nawyku wąchania genitaliów innych osobników, jak robią to psy, a wzrok uzyskał przewagę nad powonieniem. Zmysł powonienia został zarazem odcięty od wyższych poziomów intelektu. Taniec stanowi tutaj możliwe połączenie pomiędzy pamięcią cielesną i mózgiem, a więc także pomiędzy wykorzystywanymi przez nas podstawowymi zmysłami.

\section{Widzowie, publiczność, uczestnicy i człowieczeństwo}

Pierwsze przykłady nowego rodzaju strategii choreograficznych łączących wiedzę z pamięcią ciała poprzez to, co nazywamy tutaj naskórkowością, paradoksalnie mogą odwoływać się do powszechnego słownika ruchu tanecznego. W tym znaczeniu choreografia może np. rozwijać tradycyjną formę „jeden na jed- 
nego" w układzie: amator i profesjonalny tancerz. Jako studium przypadku wykorzystuję performans Sense-action Tomasza Ciesielskiego i Kuby Pałysa (Ciesielski 2017). Poprzez strategię wplatania teorii w praktykę (zob. Ciesielski 2016) temu zespołowi udało się skorelować ustalenia naukowe z realizacją artystyczną. Choreografia Sense-action łączy węch i ruch, a także zgłębia to, jak wchodzą one ze sobą w interakcje.

Taniec jest nierozerwalnie związany z życiem i doświadczeniem, a przez to skupia uwagę na sztuce oddychania i tym, jak łączy się ona z procesami poruszania się i życia. Razem z oddechem naskórkowość kształtuje nasze doświadczanie w choreografii i odwrotnie - choreografia pozostaje wartością obecną zarówno w przedstawieniu artystycznym, jak i w prawdziwym życiu. W projekcie Sense-action wspomnienia są aktualizowane niezwykle intertekstualnie, w znaczeniu wyrażonym wcześniej, i jednocześnie niezwykle konkretnie - na odległość oddechu. Poprzez choreografię jeden z uczestników performuje ciało pełne traumy, które w pas de deux przenosi go i prowadzonego przez niego partnera $\mathrm{w}$ przestrzeń przeszłości doświadczanej z zamkniętymi oczami. Poruszanie się w ciemnościach wzmacnia naskórkowo więzy zaufania pomiędzy odbiorcą i performerem. Tematem są wspomnienia Holokaustu. W swoich wspomnieniach Laurence Langer sugeruje, że pamięć i węch są ze sobą powiązane, a sam zmysł węchu działa w takich sytuacjach w złożony sposób:

Ludzki rytuał odnowienia oznaczał nauczenie się na nowo starych nawyków z „poprzedniego", przedoświęcimskiego życia: jak korzystać ze szczoteczki do zębów, papieru toaletowego, chusteczki do nosa, noża i widelca. Jak się uśmiechać, najpierw ustami, a potem oczami. Jak odzyskać zapomniane zapachy i smaki, na przykład zapach deszczu. Ukryty, wtopiony w rytuał odnowienia przez zakłócające spokój wspomnienia, jest jednak „wbrew-czas” Auschwitz, gdzie deszcz cuchnął sraczką i spadał na obóz, ofiary, „starego dziada z krematoriów i smród płonącego ciała” (Langer 1991).

Zarówno koordynacja ruchów, jak i wybrana ścieżka oraz słownik ruchów mają pewne znaczenie dla zapachów, które są w tym projekcie traktowane jako zmienna. Pierwszym zapachem jest sztuczna wanilia, później chleb i mięta. Ponieważ projekt jest $\mathrm{w}$ toku, badane są również inne zapachy. Warunki bywają także improwizowane. Każdy z wykorzystywanych zapachów jest przejściowym elementem choreografii związanej dla uczestników z lękiem i zapachem potu jako znaczącymi. Sense-action, poza stymulacją zmysłów, wykorzystuje szereg narzędzi, w których czytelna jest naskórkowość. Narzędzia te służą wywoływaniu wspomnień i budowaniu zaufania nie tylko pomiędzy publicznością i tancerzami, ale także pomiędzy amatorem a profesjonalnym tancerzem. Najważniejsze, aby prowadzący empatyzował $\mathrm{z}$ amatorem i szanował siłę, której potrzebuje on, aby utrzymać się przy życiu - w trakcie performansu role się zmieniają. Niezwykle 
istotnym aspektem dla skuteczności performansu jest podjęcie przez prowadzącego decyzji o nawiązania kontaktu „na scenie”, podobnego do wsparcia partnera nękanego lękiem scenicznym. Wykorzystując scenerię Holokaustu w podobny sposób jak ta choreografia, pisarka Wendy Lawer (Lawer 2013, s. 91) pokazuje, jak bardzo wrażliwi stają się ludzie odczuwający lęk i gniew, gdy poczują zapach innego człowieka: „Tatuś ma rację. Ludzie bez moralnych zahamowań wydzielają dziwną woń. Już umiem ich rozpoznać: wielu naprawdę śmierdzi krwią. Mamusiu, świat jest jedną ogromną rzeźnią". W tym sensie pomiędzy uczestnikami powstaje dwojaka interakcja na poziomie naskórkowości: jedna pomiędzy wykonawcami (prowadzącym i prowadzonym), a druga pomiędzy tancerzem a publicznością. Pojawia się pytanie: w jaki sposób choreografia - oprócz muzyki i aspektu wizualnego - może budować taką więź, modelując empatię jak najbliższą człowieczeństwu?

Koncepcja tworzenia specjalnych zapachów wywołujących wspomnienia, które z kolei mogą stymulować słownik ruchów, może pomóc nam zdefiniować nieopisane dotąd aspekty ludzkiej komunikacji. Ta fascynująca, rozwijająca się dziedzina wydaje się ogniwem spajającym sztukę i codzienność. Strategie choreograficzne powinny ją uwzględniać w sposób szczególny, jako że nawet na polu technologii pojawiła się w ostatnim dziesięcioleciu strategia „brudzenia rąk”. Jak to ujął John Richards (Richards 2008) - „technologia cyfrowa jedynie podkreśliła, jak ważne są ludzkie ciało i fizyczność w występach na żywo”. Obserwując spektakl na ekranie lub z ostatnich rzędów zapełnionego teatru, widz nie poczuje zapachu tancerza. Poczuje natomiast wymieszane człowieczeństwo własnych reakcji i reakcji innych odbiorców, będących świadkami zrzucenia brzemienia na scenie. W Sense-action tancerze mogą poczuć (i dotknąć) swoich tymczasowych partnerów i w ten sposób odkodować kluczowe składniki ich fizycznego i emocjonalnego stanu. Uzyskane w ten sposób dane można wykorzystać do ulepszenia dzieła, jakim jest współtworzona przez nich jako prowadzących choreografia. Spektakl staje się bardziej empatyczny, a odbiorca odczuwa go intensywniej, łącząc intelektualne czytanie performansu z przetwarzaniem bodźców sensorycznych, w tym zapachowych.

Jako wykonawcy choreografii, skupiając się na wdechach i wydechach, pojmujemy rytm łączący wszystkie ciała w synergii uczestniczenia w akcie artystycznym. Fizyczność ciała w tańcu i sztukach performatywnych, dzięki zwiększeniu intensywności zapachu potu i zaangażowaniu oddechu, wreszcie pozwala nam zdysocjować sterylne otoczenie nowoczesnego życia, gdzie - zgodnie z Freudowskim poglądem na cywilizację - krzywo patrzy się na niekulturalne zapachy jako na prymitywne. Możemy za to powrócić do fowizmu, z jego instynktownością i nieodzownością, wyzbywając się przekombinowanej koncepcji wyreżyserowanej seksualności, a inwestując każdy aspekt życia w wydawałoby się z utęsknieniem oczekiwany prymitywizm. Aby dotknąć głębi id, wypływamy na powierzchnię i korzystamy z naskórkowości. 


\section{Wnioski}

Artykuł postuluje szczególne rozumienie człowieczeństwa jako jednego z podstawowych aspektów tworzenia strategii choreograficznej. Ta teza pociąga za sobą pytanie: w jaki sposób doskonalić wszystkie zmysły równocześnie, jeżeli nie jesteśmy gotowi zaangażować się w proces, który otwiera nas na wszystkie żywioły, w tym nasze własne zapachowe człowieczeństwo? Historia i przyszłość tańca dostarczają - poprzez oddech oraz zmysł dotyku - przesłanek na temat komunikacji, które mogą zredefiniować transdyscyplinarny słownik rozrywki i interakcji. W ten sposób może powstać nowy model interakcji, w którym kultywuje się opartą na fizycznej komunikacji tancerza i odbiorcy empatię. Uzdolniona publiczność świadomie wykorzystuje oddech i zdaje sobie sprawę z tego, że dzięki aktowi życia i oddychania wspólna przestrzeń jest trwała i staje się częścią aktu widzenia, słyszenia, poruszania się oraz jest źródłem przyjemności czerpanej z komunikacji i dzielenia się wspomnieniami.

Przekład: Tomasz Ciesielski

\section{Bibliografia}

Ashenburg K. (2009), Historia brudu, thum. A. Górska, Bellona, Warszawa.

Axel R. (2004), Scents and Sensibility: A Molecular Logic of Olfactory Perception, wykład noblowski, grudzień 2004 www.nobelprize.org/nobel_prizes/medicine/laureates/2004/axel-lecture.html (dostęp: 18.09.2017).

Blom L.A., Tarin Ch.L. (1982), The Intimate Act of Choreography, University of Pittsburgh Press, Pittsburgh.

Bois Y., Krauss R. (1996), L’Informe. Mode d'Emploi, Centre Georges Pompidou, Paris.

Bushdid C. i in. (2014), Humans can Discriminate more than 1 trillion Olfactory Stimuli, „Science”, t. 343, nr 6177.

Ciesielski T. (2016), Contemporary dance theatre in neurocognitive perspective - Granhøj Dans case, „Theatralia”, t. 19, nr 2.

Ciesielski T. (2017), Sense-action - praktyka-jako-badanie rozpoznana ex-post, w niniejszym tomie.

Craig J., Rollman G.B. (1999), Somesthesis, „Annual Review of Psychology”, t. 50.

Fontana F., Visell Y. (2012), Walking with the Senses. Perceptual techniques for walking in Simulated Environments, Logos Verlag, Berlin.

Fromm E. (1980), Greatness and Limitations of Freud's Thought, Harper and Row, New York.

Hinton E. i in. (2004), Olfactory - Triggered Panic Attacks Among Khmer Refugees, „Transcultural Psychiatry", nr 41(2).

Hollins M. (2010), Somesthetic Senses, „Annual Review of Psychology”, t. 61. 
Lang P.J. i in. (2000), Fear and Anxiety: Animal Models and Human Cognitive Psychophysiology, "Journal of Affective Disorders", t. 61, nr 3.

Langer L. (1991), Holocaust Testimonies: The Ruins of Memory, Yale University Press, New Haven.

Lemi E. (2016), Parenthetical Windows: A Project Concerning the Way in which Light and Sound Architecture affects Human Perception of Norms, ISSC 2016, International Conference Proceedings. The Logics of Image: Visualization, Iconicity, Imagination and Human Creativity, Santoriny (w druku).

Lower W. (2013), Hitler's Furies: German Women in the Nazi Killing Fields, Houghton Mifflin Harcourt, Boston. Wydanie polskie: Furie Hitlera. Niemki na froncie wschodnim, tłum. B. Gadomska, Czarne, Wołowiec 2015.

Lyman B.J., McDaniel M.A. (1990), Memory for Odors and Odor Names: Modalities of Elaboration and Imagery, „Journal of Experimental Psychology. Learning, Memory and Cognition", t. 16, nr 4.

Masqelier A. (red.) (2005), Dirt, Undress and Difference. Critical Perspectives on the Body's Surface, Indiana University Press, Bloomington.

Nietzsche F. (1974), The Gay Science, The Random House, New York. Wydanie polskie: Wiedza radosna, tłum. L. Staff, Nietzsche Seminarium, Łódź-Wrocław 2010.

Ramachandran V.S., (2000), Neurology and Passion for Art, 40/40 Visual Lectures (UCSD Faculty Lecture Series) 11/2000, www.youtube.com/watch?v=0NzSh-MiqKgQ (dostęp: 18.09.2017).

Ramachandran V.S, Hirstein W. (1999), The science of art: A neurological theory of aesthetic experience, „Journal of Consciousness Studies”, nr 6.

Richards J. (2008), Getting the hands dirty, „Leonardo Music Journal” t. 1, DOI: 10.1162/ lmj.2008.18.25.

Schülting S. (2016), Dirt in Victorian Literature and Culture: Writing Materiality, Routledge, London.

Serlin I.A. (1996), Body as Text: A Psychological and Cultural Reading, „The Arts in Psychotherapy", t. 23, nr 2.

Stein E.K. (2009), Anatomie des Materials, Heidelberg, arthistoricum.net, URN:nbn:de:bsz:16-neuw-304798.

Vosnaki E., Perfums in Dialogue with One Another, „Calameo Magazine”, http://en.calameo.com/read/0000376994d7708efe339 (dostęp: 15.07.2017).

Yesurun Y., Sobel N. (2010), An Odor is Not Worth a Thousand Words. From Multidimensional Odors to Unidimensional Odor Objects, „Annual Review of Psychology”, t. 61 .

\section{Summary}

The art of breathing connects us with the artefact in question, exchanging information between the inner and outer world with no glamorisation, since humanness forms part of it. Therefore the syntax of things re-arranges itself in free association with memory, in silent mode, working on the first impression triggered, thus shaping our experience. As we comprehend the world through all our senses in collaboration in order to interact, memory plays a significant role in expressing and communicating what lies in-between; The body remembers things that 
we can barely explain, on a kinaesthetic level and on the level of communication and expression as well. The term Hautlichkeit in this sense could suggest the significant importance of creating a new vocabulary that we may use in embodied performance connecting choreography, haptics and transdisciplinary art, as sweat and human touch is still necessary there, when in all other art forms sweat and touch seems to be an in-context subject and not the natural tool within which we achieve communication. 